\title{
Biosynthesis of Silver Nanoparticles Using Stenocereus queretaroensis Fruit Peel Extract: Study of Antimicrobial Activity
}

\author{
Eduardo Padilla-Camberos ${ }^{1, *}$, Ivan Moises Sanchez-Hernandez ${ }^{1}$, Omar Ricardo Torres-Gonzalez ${ }^{1}(\mathbb{D}$, \\ Patricia Ramirez-Rodriguez ${ }^{1}$, Emmanuel Diaz ${ }^{1} \oplus$, Holger Wille ${ }^{2} \oplus$ and Jose Miguel Flores-Fernandez ${ }^{2,3, *}$ \\ 1 Unit of Medical and Pharmaceutical Biotechnology, Center for Research and Assistance in Technology and \\ Design of the State of Jalisco, A.C. (CIATEJ), Guadalajara 44270, Jalisco, Mexico; \\ isanchez@ciatej.mx (I.M.S.-H.); polimerasados@gmail.com (O.R.T.-G.); acineto123@hotmail.com (P.R.-R.); \\ ediaz@ciatej.mx (E.D.) \\ 2 Department of Biochemistry \& Centre for Prions and Protein Folding Diseases, University of Alberta, \\ 204 Brain and Aging Research Building, Edmonton, AB T6G 2M8, Canada; wille@ualberta.ca \\ 3 Department of Research and Innovation, Universidad Tecnológica de Oriental, Oriental 75020, Puebla, Mexico \\ * Correspondence: epadilla@ciatej.mx (E.P.-C.); jose.flores@utdeoriental.edu.mx or floresfe@ualberta.ca (J.M.F.-F.); \\ Tel.: +52-(33)-33455200 (ext. 1640) (E.P.-C.); +1-(825)-9931702 (J.M.F.-F.)
}

\section{check for}

updates

Citation: Padilla-Camberos, E.; Sanchez-Hernandez, I.M.; TorresGonzalez, O.R.; Ramirez-Rodriguez, P.; Diaz, E.; Wille, H.; Flores-Fernandez, J.M. Biosynthesis of Silver Nanoparticles Using Stenocereus queretaroensis Fruit Peel Extract: Study of Antimicrobial Activity. Materials 2021, 14, 4543. https://doi.org/ $10.3390 / \mathrm{ma} 14164543$

Academic Editor: Miruna Silvia Stan

Received: 18 July 2021

Accepted: 9 August 2021

Published: 12 August 2021

Publisher's Note: MDPI stays neutral with regard to jurisdictional claims in published maps and institutional affiliations.

Copyright: (c) 2021 by the authors. Licensee MDPI, Basel, Switzerland. This article is an open access article distributed under the terms and conditions of the Creative Commons Attribution (CC BY) license (https:/ / creativecommons.org/licenses/by/ $4.0 /)$.

\begin{abstract}
The synthesis and application of nanomaterials as antioxidants and cytotoxic agents has increased in recent years. Biological methods go beyond the chemical and physical synthesis that is expensive and not friendly to the environment. Foodborne pathogens and microorganisms causing candidiasis are responsible of $5-10 \%$ hospitalized patients. The nutritional properties of the fruit called pitaya, from the Stenocereus queretaroensis species, have been little explored. Therefore, in this study the phytochemical composition of $S$. queretaroensis peel was evaluated and silver nanoparticles (AgNPs) were synthesized biologically in an environmentally friendly way by S. queretaroensis peel aqueous extract that contains phytochemicals capable of reducing silver nitrate. The antimicrobial activity of the AgNPs was tested by determining the minimum inhibitory concentration (MIC), minimal bactericidal concentration (MBC) and time-kill kinetics. AgNPs were characterized visually, by UV-visible spectroscopy and TEM. FTIR spectroscopy identified metabolites responsible for the AgNPs formation. AgNPs showed potent antimicrobial activity against gram-negative and grampositive bacteria, against fungi, and a methicillin-resistant strain of $S$. aureus. MIC and MBC values were as low as 0.078 and $0.156 \mu \mathrm{g} / \mathrm{mL}$ using AgNPs biosynthesized by S. queretaroensis fruit peel and the time kill assay started a $\log$ reduction in $\mathrm{CFU} / \mathrm{mL}$ at $1 \times \mathrm{MIC}$ and $2 \times \mathrm{MIC}$. S. queretaroensismediated AgNPs could be the basis for the formulation of biofilms for packaging products or as disinfectants for use on different surfaces.
\end{abstract}

Keywords: nanoparticles; biosynthesis; antimicrobial activity; Stenocereus queretaroensis peel extract; pitaya peel

\section{Introduction}

Over the years, interest in the development of nanomaterials has increased exponentially, in particular the use of silver nanoparticles (AgNPs), because of its applications as antimicrobials, antioxidants and cytotoxics [1,2]. Silver nanoparticles are synthetized through chemical and physical methods. However, those methods require expensive equipment and are not environmentally friendly due to the toxic chemicals that are used in their production. The biological method stands out as a variant for the generation of nanoparticles (NP) with plant extracts, since the waste generated presents a lesser impact on the environment, energy, and resources, being, in general, an easy, fast and economical process [3]. 
The antimicrobial activity of AgNPs biosynthesized with different plant extracts has become of great interest to the industry, as bacteria that can be found in food, and inert surfaces that we touch can cause poisonings that are harmful to human health. About $5-10 \%$ of hospitalized patients in intensive care suffer from infections due to food poisoning. Some Enterobacteriaceae such as Enterobacter cloacae, Escheríchía coli and Salmonella spp., as well as gram-positive bacteria, such as Clostrídíum perfringens and Clostridium botulinum, and gram-positive cocci (Staphylococcus aureus), which can be found almost anywhere, are responsible for such infections [4].

A search for antimicrobials that can be used against these bacteria on both living and inert surfaces, and which also do not generate resistance in a short time, is of paramount importance as biosynthesized nanoparticles have variable effects depending on the compounds of the source (plant, fungi, weed, lichen, etc.) used as reducers [5].

Fruit peels have been used in a few studies to biosynthesize silver nanoparticles, but the distinctive band of silver nanoparticle biosynthesis in the UV-visible spectrum around $410-450 \mathrm{~nm}$ is missing from existing reports [6]. Furthermore, cladodes from Opuntia spp. and the Ferocactus echidne plants belonging to the Cactaceae (cactus) family have been used for biosynthesis of silver nanoparticles [7,8]. However, as of yet, there is no report of cactus fruit peel for this purpose. Stenocereus queretaroensis is another cactus species with a wide distribution in the Americas, particularly in Mexico, where its fruit, known as pitaya, has been part of the diet of the inhabitants of semi-arid regions since pre-Hispanic times [9]. Commercial use of the pitaya has not been studied due to a general lack of knowledge regarding its nutritional properties. Its composition is characterized by the presence of water-soluble nitrogenous pigments named as betalains that are divided into two structural groups, betacyanins, which give it its color from reddish to violet and betaxanthins conferring a yellow-orange coloration [10]. These pigments possess antioxidant, cytotoxic and anti-inflammatory properties. Moreover, the presence of ascorbic acid (vitamin C) and reducing sugars in the peel [11] is of special interest in accordance with other authors due to their role as silver reducers in the green synthesis of nanoparticles [12]. Nevertheless, the information on the composition of the pitaya peel is very limited; therefore, in this study its phytochemical composition has been evaluated and, for the first time, the synthesis and characterization of silver nanoparticles using an aqueous extract of S. queretaroensis fruit peel is reported. In addition, the antimicrobial activity of the synthesized AgNPs against strains of industrial and medical interest was evaluated.

\section{Materials and Methods}

\subsection{S. queretaroensis Peel Extract}

S. queretaroensis fruit was purchased from a market in Jalisco, Mexico. The extract was obtained according to the methodology published by Loo et al. [13] with some modifications. Briefly, the pitaya peels were dried at $60^{\circ} \mathrm{C}$ for 5 days in a stove and then crushed and pulverized by a blender (Hamilton Beach, Henrico County, VA, USA), and finally packed and stored at room temperature (RT); $1.0 \mathrm{~g}$ of $S$. queretaroensis dehydrated peel was homogenized in $100 \mathrm{~mL}$ of distilled water and was kept boiling for $5 \mathrm{~min}$, and then filtered on Whatman 40 at RT to remove particles and prevent organic matter (Scheme 1). Finally, the $S$. queretaroensis peel aqueous extract was placed in an amber container and kept at $4{ }^{\circ} \mathrm{C}$ until further use.

\subsection{Phytochemical Analysis of S. queretaroensis Peel Aqueous Extract}

The presence of bioactive compounds of the S. queretaroensis peel aqueous extract was determined by qualitative analysis of flavonoids, phenols, glycosides, tannins, saponins and alkaloids. Flavonoids were determined by aluminum chloride and phenols by FolinCiocalteu's method as described by Marinova et al. [14]. Moreover, glycosides and tannins were determined by Fehling's method [15]. Saponins were determined according to the method described by Ejikeme et al. [16] and alkaloids by Dragendorff's method according to Rivas et al. [9] with modifications. Tests were carried out in triplicate. 


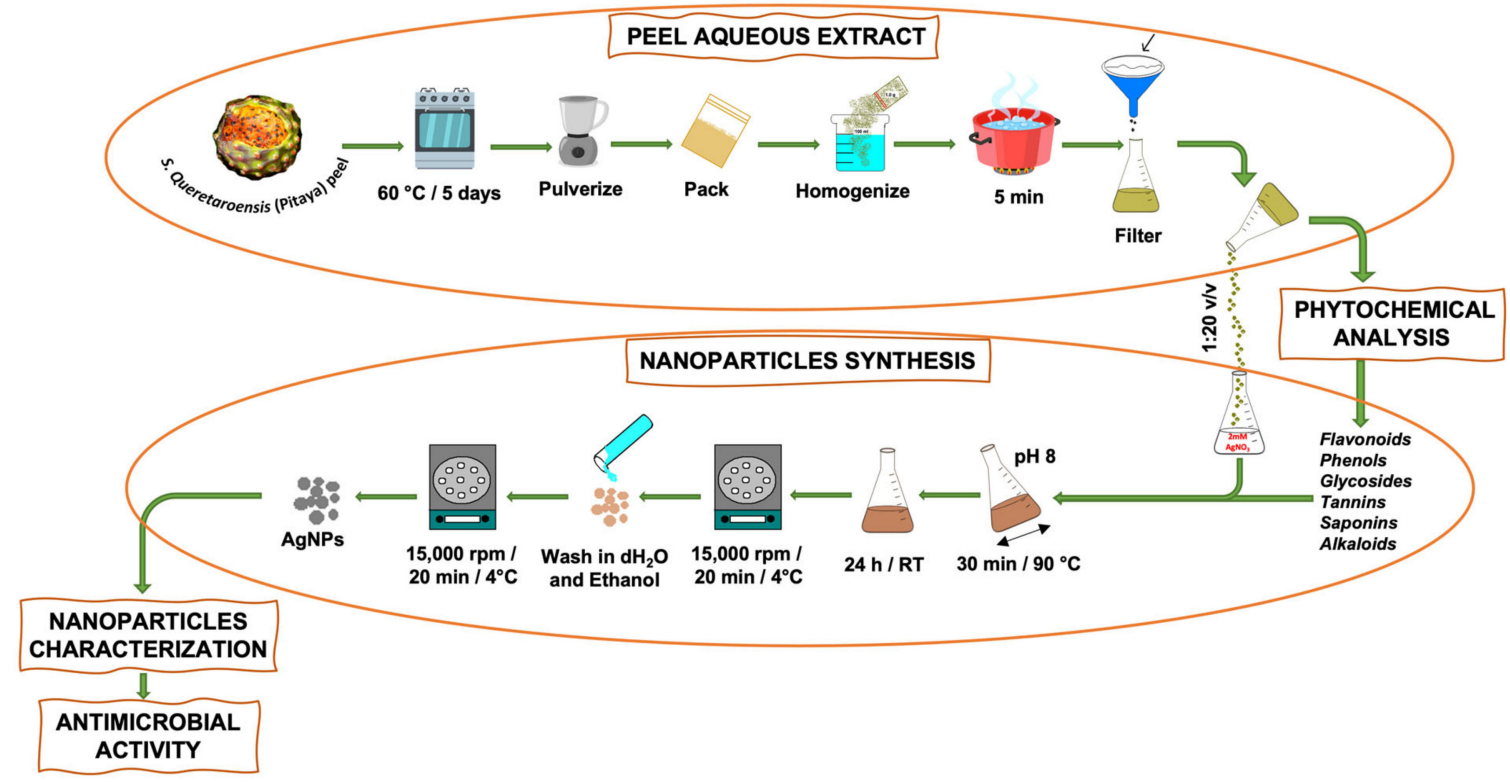

Scheme 1. The process of obtaining the S. queretaroensis peel aqueous extract and the biosynthesis of S. queretaroensismediated silver nanoparticles are depicted in a schematic diagram.

\subsection{Synthesis of Silver Nanoparticles}

Silver nanoparticles were synthesized by adding $S$. queretaroensis peel aqueous extract to a $2 \mathrm{mM}$ silver nitrate $\left(\mathrm{AgNO}_{3}\right)$ solution at a volume ratio of 1:20. The $\mathrm{pH}$ was adjusted to 8 using $1 \mathrm{M} \mathrm{NaOH}$. The mixture was stirred for $30 \mathrm{~min}$ at a temperature of $90^{\circ} \mathrm{C}$ and subsequently allowed to cool and stand for $24 \mathrm{~h}$ at room temperature to end the reaction. The formation of colloidal AgNPs was observed by the color change to reddish brown. Subsequently, the nanosilver solution was centrifuged at $15,000 \times \mathrm{g}$ rpm for $20 \mathrm{~min}$ at $4{ }^{\circ} \mathrm{C}$ and supernatant was discarded. Finally, the pellet was washed with distilled water five times to remove impurities and once with $90 \%$ ethanol to obtain pure S. queretaroensismediated AgNPs (Scheme 1).

\subsection{Characterization of S. queretaroensis-Mediated Silver Nanoparticles}

\subsubsection{UV-Visible Spectroscopy}

Bioreduction of the $\mathrm{AgNO}_{3}$ to $\mathrm{S}$. queretaroensis-mediated AgNPs was analyzed using UV-Vis Spectrophotometer (xMark, Bio-Rad, Hercules, CA, USA). Samples were loaded into a $1 \mathrm{~cm}$ path length quartz cuvette. The resolution of the equipment was one $\mathrm{nm}$, and a scan in the wavelength range of 300 to $700 \mathrm{~nm}$ was carried out.

\subsubsection{Fourier Transform Infrared Spectroscopy (FTIR)}

Biomolecules responsible for the biosynthesis of S. queretaroensis-mediated AgNPs were identified by infrared spectroscopy; $30 \mu \mathrm{L}$ of sample was placed on an Agilent Cary 630 FTIR Spectrometer (Agilent Technologies, Santa Clara, CA, USA). Transmittance measurements of the $S$. queretaroensis peel aqueous extract and pure AgNPs were carried out in the $4000-400 \mathrm{~cm}^{-1}$ range, at a resolution of $4 \mathrm{~cm}^{-1}$. MicroLab software (Agilent Technologies, Santa Clara, CA, USA) was used to ascertain peak values.

\subsubsection{Dynamic Light Scattering (DLS)}

The particle size distribution of S. queretaroensis-mediated AgNPs was measured by DLS. Measurement was repeated in triplicate at $25^{\circ} \mathrm{C}$ and performed using a Zetasizer equipment (Nano ZS, Malvern, UK). 


\subsubsection{Transmission Electron Microscopy (TEM)}

$5-\mu \mathrm{L}$ drops of nanoparticles in colloidal solution, diluted in distillated water (1:50) and in its pure form were dropped onto freshly glow-discharged 400 mesh carbon coated copper grids (Electron Microscopy Sciences, Hatfield, PA, USA) and were allowed to dry at room temperature.

The morphology and the size distribution of the biosynthesized silver nanoparticles were evaluated by transmission electron microscopy using a Tecnai G20 instrument (FEI Company, Hillsboro, OR, USA) operated at an acceleration voltage of $200 \mathrm{kV}$. Electron micrographs were acquired with an Eagle $4 \mathrm{k} \times 4 \mathrm{k}$ CCD camera (FEI Company, Hillsboro, OR, USA) at nominal magnifications of $11,500 \times, 50,000 \times$ and $62,000 \times$.

\subsection{Antimicrobial Activity}

The minimum inhibitory concentration (MIC), minimal bactericidal concentration (MBC) and Time-kill methods [17] were performed to evaluate the antimicrobial activity of S. queretaroensis-mediated AgNPs.

\subsubsection{Minimum Inhibitory Concentration (MIC) Determination}

Gram-negative bacteria (Escherichia coli ATCC 11229, Salmonella enterica ATCC 10708, Pseudomonas aeruginosa ATCC 9027), gram-positive bacteria (Staphylococcus aureus ATCC 6538, methicillin-resistant S. aureus (MRSA) ATCC 43300), and the mold Candida albicans ATCC 10231 were purchased from American Type Culture Collection (Rockville, MD, USA), and cultured in Mueller Hinton broth (Merk, Germany) at $37^{\circ} \mathrm{C}$ and $200 \mathrm{rpm}$ for $24 \mathrm{~h}$. $1 \mathrm{~mL}$ bacterial inoculum was inoculated at $1.5 \times 10^{8} \mathrm{CFU} / \mathrm{mL}$ in 24-well polystyrene plates. Then, eight serial 2-fold dilutions were prepared from the concentration of $10 \mu \mathrm{g} / \mathrm{mL}$ S. queretaroensis-mediated AgNPs and of the S. queretaroensis peel aqueous extract and $0.5 \%$ DMSO (dimethylsulfoxide) was used as negative growth control and MHB broth plus bacterial inoculum as growth control. Antibiotics according to the CLSI guidelines [18] as positive controls were used to validate the test. The plate was incubated at $37^{\circ} \mathrm{C}$ for $24 \mathrm{~h}$ and the MIC value was determined as the last serial dilution where no visible bacterial growth was noticed by turbidity and color change. Tests were carried out in triplicate.

\subsubsection{Minimal Bactericidal Concentration (MBC) Determination}

The MBC was determined from the last three wells that showed no bacterial growth from MIC test. Then, $10 \mu \mathrm{L}$ from the corresponding wells were plated on nutritive agar plates. The plates were incubated at $37^{\circ} \mathrm{C}$ for $24 \mathrm{~h}$. The $\mathrm{MBC}$ was determined as the lowest concentration of the S. queretaroensis-mediated AgNPs or S. queretaroensis peel aqueous extract that prevented growth of more than one CFU. Tests were carried out in triplicate.

\subsubsection{Time-Kill Kinetics Assay}

$100 \mu \mathrm{L}$ of inoculum of each strain at 0.5 of the McFarland scale $\left(1.5 \times 10^{8} \mathrm{CFU} / \mathrm{mL}\right)$ was mixed with biosynthesized AgNPs diluted in nutrient broth at concentrations of $0 \times$ MIC, $\frac{1}{2} \times$ MIC, $1 \times$ MIC and $2 \times$ MIC (MIC values were obtained from the experiments described above in Section 2.5.1) at final volume of $1 \mathrm{~mL}$, and then incubated at $37^{\circ} \mathrm{C}$ at $150 \mathrm{rpm}$. Subsequently, $100 \mu \mathrm{L}$ of each culture was spread on nutrient agar plates at different time points $(0,15,30,60$ and $120 \mathrm{~min})$ and incubated overnight at $37^{\circ} \mathrm{C}$. The number of colonies was quantified as colony forming units (CFU) per $\mathrm{mL}$ of bacterial culture. The tests were performed in triplicate.

\subsection{Data Analysis}

Data were analyzed as viable bacterial cell curves over time. $\mathrm{CFU}$ were represented as $\log 10$ per milliliter $(\mathrm{CFU} / \mathrm{mL})$ versus time in minutes. Bactericidal activity was defined as a reduction of $\geq 3 \log 10(\mathrm{CFU} / \mathrm{mL})$ in relation to the initial population, while bacteriostatic activity corresponds to a decrease of $<3 \mathrm{Log} 10(\mathrm{CFU} / \mathrm{mL})$ in relation to the initial population of each strain. 


\section{Results}

\subsection{Phytochemical Components of S. queretaroensis Peel Aqueous Extract}

The phytochemical analysis of the $S$. queretaroensis peel aqueous extract qualitatively revealed the presence of saponins, glycosides, and flavonoids in appreciable amounts, while alkaloids, tannins, and phenols were present in moderate quantities (Table 1).

Table 1. Phytochemical components of S. queretaroensis peel aqueous extract.

\begin{tabular}{cc}
\hline Test Name & Results \\
\hline Test for saponins & +++ \\
Test for glycosides & ++ \\
Test for alkaloids & + \\
Test for tannins & + \\
Test for flavonoids & ++ \\
Test for phenols & + \\
\hline+++ appreciable amounts ++: moderate amounts +: low amounts. The tests were performed in triplicate.
\end{tabular}

\subsection{Synthesis and Characterization of S. queretaroensis-Mediated Silver Nanoparticles}

The $S$. queretaroensis peel aqueous extract interacted with the silver nitrate salt solution (colorless) forming a light-yellow color solution that later changed to a dark reddish-brown color, indicating the reduction of ionic silver to reduced silver and the subsequent synthesis of AgNPs (Figure 1). A broad peak near $420 \mathrm{~nm}$ in the UV-visible spectra confirmed the synthesis of S. queretaroensis-mediated AgNPs (Figure 2), while the S. queretaroensis peel aqueous extract showed strong absorption below $400 \mathrm{~nm}$. The colorless silver nitrate solution had no appreciable peak in visible light spectrum.

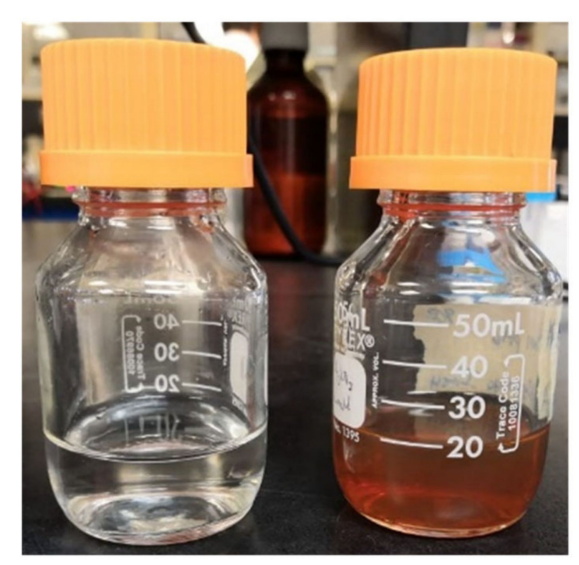

Figure 1. Biosynthesis of silver nanoparticles mediated by aqueous S. queretaroensis peel extract. Silver nitrate salt solution (colorless) converted into a light-yellow colored solution that later changed to a dark reddish-brown color.

\subsubsection{FTIR Spectral Analysis}

FTIR analysis of nanoparticles compared to $S$. queretaroensis peel aqueous extract was performed to identify the biomolecules responsible for the reduction of silver nitrate of the biosynthesized AgNPs by S. queretaroensis peel aqueous extract. FTIR spectrum of the extract showed peaks at $3500-3200 \mathrm{~cm}^{-1}$ (Hydrogen-bonded O-H stretch characteristic of phenols), $1650-1585 \mathrm{~cm}^{-1}$ (C-C=C Symmetric stretch characteristic of flavonoids and aromatic rings), and a peak at $1100-1000 \mathrm{~cm}^{-1}$ characteristic of sugars such as fructose or glucose and C-O bonds within the alcohols (Figure 3a), while in the FTIR spectra of S. queretaroensis-mediated AgNPs, the band at $1650-1585 \mathrm{~cm}^{-1}$ was not present (Figure 3b). 


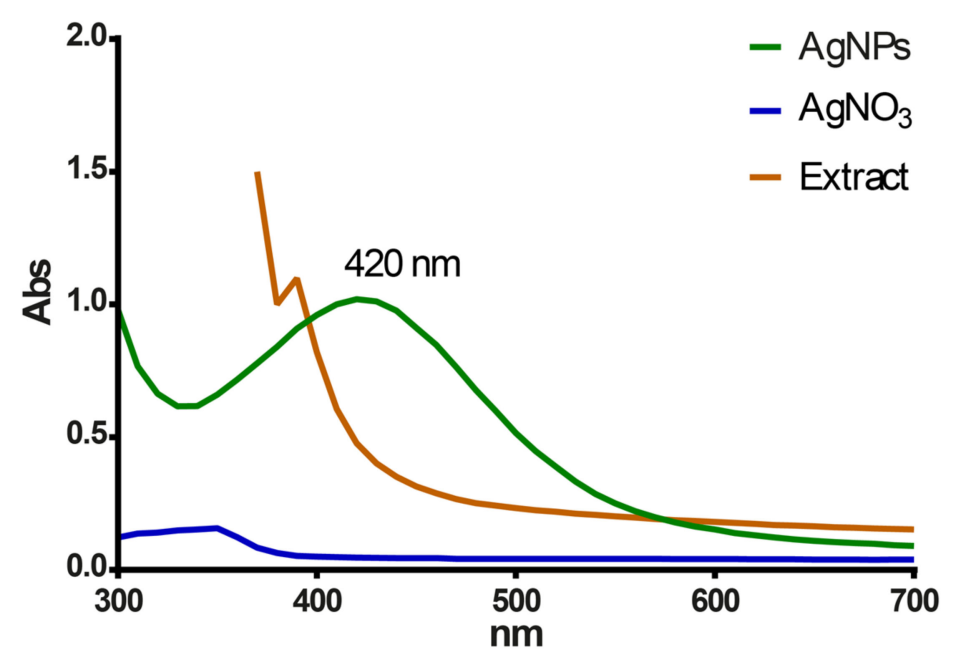

Figure 2. UV-vis absorption spectra of biosynthesized silver nanoparticles, aqueous S. queretaroensis peel extract, and silver nitrate salt solution.
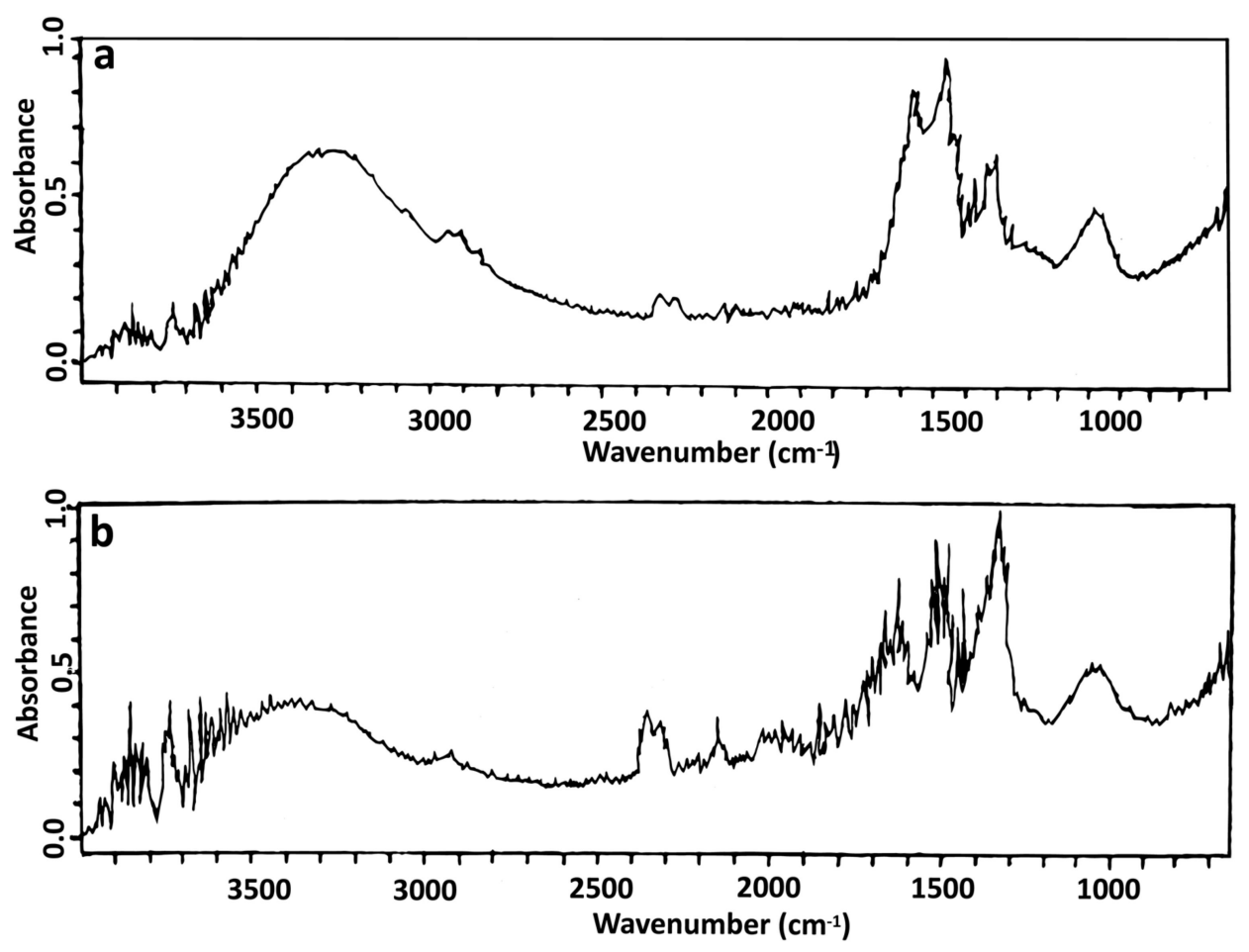

Figure 3. Fourier Transform Infrared Spectroscopy analysis of (a) S. queretaroensis peel aqueous extract and (b) biosynthesized silver nanoparticles.

\subsubsection{Particle Size Analysis}

DLS analysis displayed a size distribution of the S. queretaroensis-biosynthesized silver nanoparticles that ranged between 20 and $600 \mathrm{~nm}$ (Figure 4) with a majority of AgNPs in the range of 60 to $200 \mathrm{~nm}$ and an average particle size of $98.96 \mathrm{~nm}$.

\subsubsection{TEM Analysis}

Micrographs obtained by transmission electron microscopy to determine the shape and morphology of the S. queretaroensis-mediated AgNPs showed that the particles in colloidal solution (Figure 5a-c) and pure form (Figure 5d) were roughly spherical and uniform in shape and in addition did not create large agglomerates. 


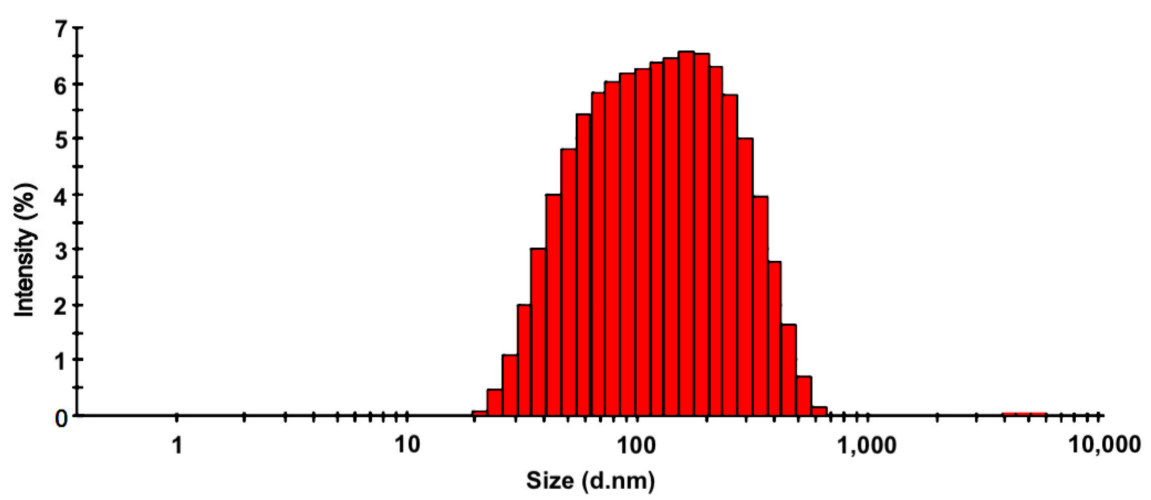

Figure 4. Size distribution of S. queretaroensis-mediated silver nanoparticles by dynamic light scattering analyses.
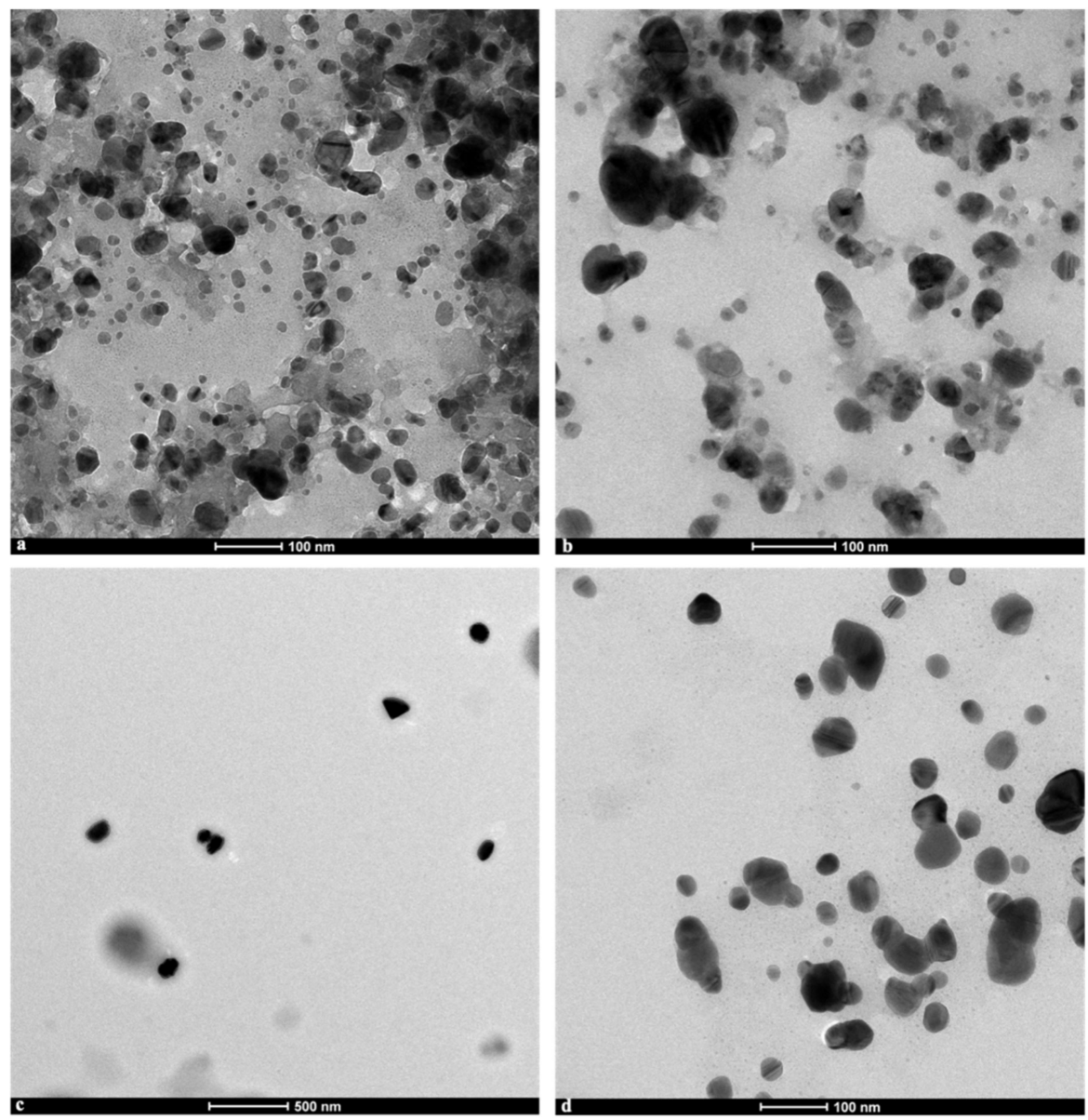

Figure 5. TEM micrographs of the silver nanoparticles biosynthesized by aqueous $S$. queretaroensis peel extract in colloidal solution at nominal magnifications of (a) 50,000×, (b) 62,000×, (c) isolated at a dilution of 1 in 50 at a nominal magnification of $11,000 \times$ and (d) in their pure form after being washed (at 50,000×). 


\subsection{Antimicrobial Activity of S. queretaroensis-Mediated AgNPs}

3.3.1. Minimum Inhibitory and Minimum Bactericidal Concentrations

The lowest concentration of the S. queretaroensis-mediated AgNPs to inhibit the growth of microorganisms ranged from 0.078 to $0.313 \mu \mathrm{g} / \mathrm{mL}$. The gram-negative bacteria S. enterica and the yeast $C$. albicans showed a MIC value of $0.078 \mu \mathrm{g} / \mathrm{mL}$ while the gram-positive bacteria $S$. aureus and methicillin-resistant $S$. aureus (MRSA) along gram-negative $E$. coli showed MIC values of $0.313 \mu \mathrm{g} / \mathrm{mL}$. Lastly, P. aeruginosa showed a MIC value of $0.156 \mathrm{ug} / \mathrm{mL}$ (Table 2).

Table 2. Minimal inhibitory concentration and minimal bactericide concentration $(\mu \mathrm{g} / \mathrm{mL})$ of biosynthesized silver nanoparticles by $S$. queretaroensis peel aqueous extract.

\begin{tabular}{ccc}
\hline Microorganism & MIC $(\mu \mathrm{g} / \mathrm{mL}){ }^{*}$ & MBC $(\mu \mathrm{g} / \mathrm{mL}){ }^{*}$ \\
\hline Gram-Negative Bacteria & & \\
E. coli & 0.313 & 0.625 \\
S. enterica & 0.078 & 0.156 \\
P. aeruginosa & 0.156 & 0.313 \\
\hline Gram-Positive Bacteria & \\
S. aureus & 0.313 & 0.625 \\
S. aureus (MRSA) & 0.313 & 0.625 \\
Yeast & \\
C. albicans & 0.156 \\
\hline${ }^{*}$ Tested in two-fold dilution steps (Starting at $\left.10 \mu \mathrm{g} / \mathrm{mL}\right)$. &
\end{tabular}

The lowest concentration of biosynthesized AgNPs by S. queretaroensis peel aqueous extract required to kill microorganisms (no growth on the agar plate) ranged from 0.156 to $0.625 \mu \mathrm{g} / \mathrm{mL}$. In the study, MBC for S. enterica and C. albicans were $0.156 \mu \mathrm{g} / \mathrm{mL}$ while S. aureus, MRSA and E. coli showed the MBC value of $0.625 \mu \mathrm{g} / \mathrm{mL}$. The gram-negative P. aeruginosa showed the lowest MBC value of $0.313 \mathrm{ug} / \mathrm{mL}$ (Table 2).

The mean values of MIC and MBC for all microorganisms tested in this study was of $0.208 \pm 0.118 \mu \mathrm{g} / \mathrm{mL}$ and $0.417 \pm 0.235 \mu \mathrm{g} / \mathrm{mL}$, respectively.

\subsubsection{Time-Kill Kinetics of AgNPs}

AgNPs biosynthesized by $S$. queretaroensis tested at concentration of $2 \times$ MIC exhibited a bactericidal effect after $2 \mathrm{~h}$ of incubation for all microorganisms tested in this study, reducing the $\log \mathrm{CFU} / \mathrm{mL}$ concentration regarding the $\log \mathrm{CFU} / \mathrm{mL}$ concentration of the first $15 \mathrm{~min}$ of incubation. E. coli and S. aureus showed a similar reduction of 2.34 and 2.46 logs (Figure 6a,b), while the strain methicillin-resistant $S$. aureus exhibited the highest reduction of $5.85 \operatorname{logs}$ (Figure 6c). The lowest reductions of 1.68, 1.63 and 1.01 logs were for S. enterica, P. aeruginosa, and C. albicans, respectively (Figure $6 \mathrm{~d}-\mathrm{f}$ ).

AgNPs evaluated at $1 \times$ MIC still showed a bactericidal effect reducing $3.4 \operatorname{logs}$ for methicillin-resistant S. aureus, 1.10 and $1.02 \operatorname{logs}$ for S. aureus and S. enterica (Figure $6 \mathrm{~b}-\mathrm{d}$ ) but for E. coli, P. aeruginosa and C. albicans the reduction was less: $0.681,0.22$ and 0.53 logs, respectively (Figure 6a,e,f).

When the AgNPs were tested at concentration of $1 / 2 \times$ MIC for E. coli, P. aeruginosa and C. albicans exhibited a bacteriostatic effect as the $\log \mathrm{CFU} / \mathrm{mL}$ over time remained roughly the same as the $\log \mathrm{CFU} / \mathrm{mL}$ concentration after the first $15 \mathrm{~min}$ of incubation (Figure 6a,e,f). 

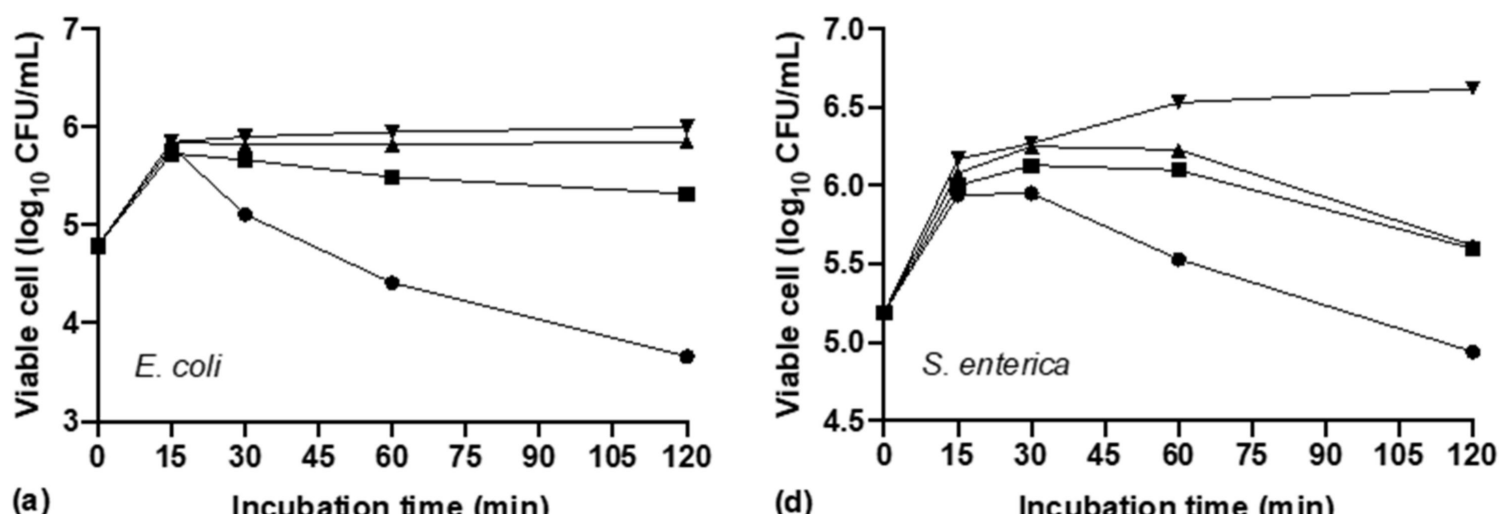

(a)

Incubation time (min)

(d)

Incubation time (min)

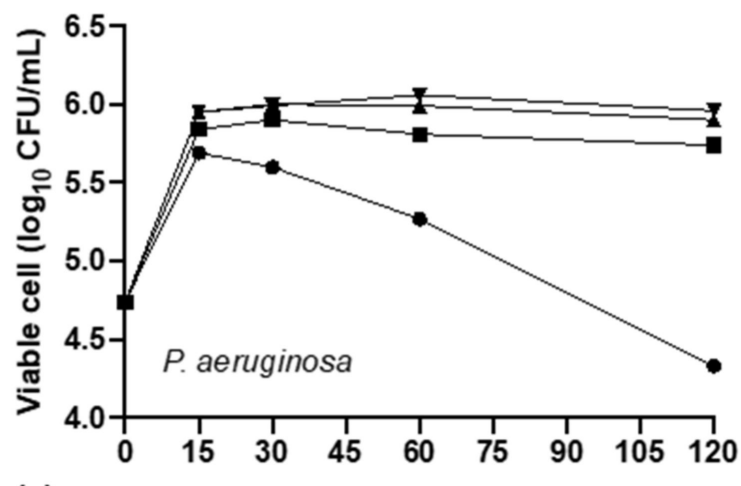

(e)

Incubation time ( $\mathrm{min}$ )

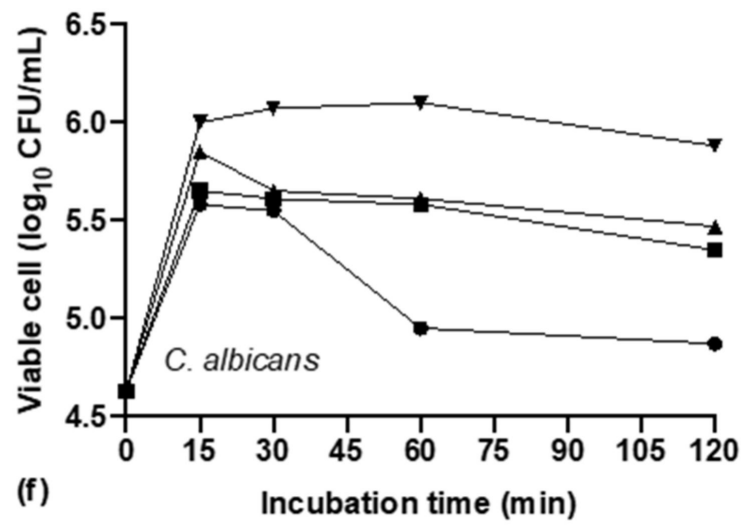

Figure 6. Time-kill kinetics of silver nanoparticles biosynthesized from S. queretaroensis against (a) E. coli, (b) S. aureus, (c) methicillin-resistant S. aureus, (d) S. enterica, (e) P. aeruginosa (f), C. albicans at three different concentrations $(\rightarrow 2$ MIC, $\rightarrow 1 \mathrm{MIC} \rightarrow 1 / 2 \mathrm{MIC}$, and $0 \rightarrow \mathrm{MIC})$ added to media containing a starting culture.

\section{Discussion}

Pitaya fruit (S. queretaroensis) lack widespread commercial use because its nutritional and biological properties are not fully known; recently, the presence of betacyanins, betaxanthins, vitamin $C$, carbohydrates, and fiber of the different parts of the fruit have been reported. Now, in this study, the phytochemical analysis of the $S$. queretaroensis peel aqueous extract qualitatively showed the presence of saponins, glycosides, and flavonoids, in considerable quantities, while alkaloids, tannins and phenols were present in moderate amounts (Table 1). These new findings add value to the pitaya fruit since those compounds have biological activities that include anti-inflammatory [19], antioxidant [20], and wound healing [21] properties, and aid in cardiovascular diseases [22], acting as sedatives [23]. 
Medicinal plants are widely used as complementary and alternative medicine due to low cost and easy access. The presence of metabolites like flavonoids, glycosides, and alkaloids in the $S$. queretaroensis peel aqueous extract as noted from phytochemical color tests prompted us to test it as a reducer for silver nitrate.

Silver nanoparticles were successfully synthesized by mixing the $S$. queretaroensis peel aqueous extract with a silver nitrate salt solution, which was indicated by the color change of the reaction from a colorless to a reddish-brown color (Figure 1). Color change is due to the reduction of ionic silver from silver nitrate into silver nanoparticles mediated by biomolecules contained in the S. queretaroensis peel aqueous extract [24]. Besides the color change monitored visually, the UV-visible absorption spectrum of the S. queretaroensismediated AgNPs showed a broad peak at $420 \mathrm{~nm}$, confirming the presence of AgNPs (Figure 2). The selected parameters for S. queretaroensis-mediated AgNPs biosynthesis was based on a review of different studies, from which a series of parameters were obtained that were supported by a response surface design and yielded a series of combinations that were tested (data not shown). Silver nitrate concentration and temperature were the most significant factors in the formation of nanoparticles.

Silver nanoparticles were characterized in this study visually (Figure 1), by UV-visible spectroscopy (Figure 2) and by TEM analysis (Figure 5) to determine its formation and by FTIR spectroscopy (Figure 3) to identify the metabolites responsible for the AgNPs formation, as well as the measurement of the nanoparticles size range by DLS analysis [25-27]. The FTIR spectrum obtained from the S. queretaroensis peel aqueous extract showed a characteristic peak of flavonoids at $1650-1585 \mathrm{~cm}^{-1}$ that was not present in the S. queretaroensis-mediated AgNPs (Figure 3), suggesting a possible biosynthesis mechanism: flavonoids hydroxyl groups bind to ionic silver $\left(\mathrm{Ag}^{+}\right)$, acting as a reducing compound to form silver metal atoms $\left(\mathrm{Ag}^{0}\right)$.

AgNPs synthesized by biological methods have shown a higher antibacterial effect regarding those synthesized by chemical methods [28]. The $S$. queretaroensis peel aqueous extract did not show any antibacterial activity at the same concentrations tested as S. queretaroensis-mediated AgNPs. Similar results have been reported where NPs have greater antimicrobial activity than plant extracts, and it has also been observed that some extracts show no activity as well [29]. An advantage that stands out from the use of nanoparticles in antimicrobial activity compared to plant extracts is that, by using a lower concentration of synthesized nanoparticles from plant extracts, it is possible to achieve an activity equivalent to plant extracts used at high concentrations [27].

MIC mean value for gram-negative bacteria was $0.182 \mathrm{ug} / \mathrm{mL}$, while for gram-positive bacteria it was $0.313 \mathrm{ug} / \mathrm{mL}$ and $0.078 \mathrm{ug} / \mathrm{mL}$ for yeast. The nanoparticles biosynthesized with pitaya peel reported in this study showed a higher antimicrobial effect (Table 2) compared to AgNPs of size 20-60 nm obtained from the Ferocactus echidne cactus [7] tested at a concentration of $0.1 \mathrm{~g} / \mathrm{mL}(>300,000$ times higher than MIC values reported in our study) against E. coli, S. aureus, and C. albicans. Unfortunately, MIC values were not evaluated for a better comparison $(1.8,2.1$ and $1.6 \mathrm{~mm}$ inhibition zones, respectively). The MIC and MBC values of 0.313 and $0.625 \mu \mathrm{g} / \mathrm{mL}$ of $S$. queretaroensis-mediated AgNPs on E. coli were 50-200 times lower compared to the MIC values reported by AgNPs biosynthesized from fruit pulp extracts of Murraya koenigii (MIC $16 \mu \mathrm{g} / \mathrm{mL}$; MBC $32 \mu \mathrm{g} / \mathrm{mL}$ ) and Theobroma grandiflorum $(31 \mu \mathrm{g} / \mathrm{mL} ; \mathrm{MBC} 125 \mu \mathrm{g} / \mathrm{mL}$ ) [30]. A similar result arose comparing the MIC and $\mathrm{MBC}$ values ( 0.313 and $0.625 \mu \mathrm{g} / \mathrm{mL}$ ) of S. queretaroensis-mediated AgNPs for S. aureus regard to AgNPs biosynthesized by Spondias mombin ( $31 \mu \mathrm{g} / \mathrm{mL}$ : MBC: $62 \mu \mathrm{g} / \mathrm{mL}$ ) and Theobroma grandiflorum ( $16 \mu \mathrm{g} / \mathrm{mL}$ : MBC $62 \mu \mathrm{g} / \mathrm{mL}$ ) [30]. Even MIC an MBC values for the drug-resistant pathogen MRSA were 100 times lower than those AgNPs biosynthesized by Murraya koenigii (MIC $32 \mu \mathrm{g} / \mathrm{mL}$ : MBC $64 \mu \mathrm{g} / \mathrm{mL}$ ) where nanoparticles had a smaller size (5-20 nm) compared to AgNPs biosynthesized by S. queretaroensis reported in this study [31]. Similarly, for C. albicans, the nanoparticles biosynthesized by Euterpe oleraceae showed MIC $(8 \mu \mathrm{g} / \mathrm{mL})$ and MBC $(31 \mu \mathrm{g} / \mathrm{mL})$ values 100-200 times higher than S. queretaroensismediated AgNPs [24,30-32]. 
MIC values describe the antimicrobial effect at a concentration after a specific time, while the time time-kill kinetics assay evaluate the effect of different concentrations of MIC obtained values (i.e., $2 \times, 1 \times$ MIC) throughout the time. The highest values of logarithm reduction showed by time-kill assay (Figure 6a-c) were obtained for the strain, methicillin-resistant $S$. aureus $(2 \times$ MIC and $1 \times$ MIC reduced 5.85 and $3.41 \operatorname{logs})$ followed by $S$. aureus $(2 \times$ MIC reduced $2.46 \operatorname{logs})$ and E. coli $(2 \times$ MIC reduced $2.34 \operatorname{logs})$. The bacteriostatic effect by $\frac{1}{2} \times$ MIC coincides with a study report by Loo et al. [24], however, the microbicidal effect by AgNPs biosynthesized by S. queretaroensis at a concentration of $2 \times$ MIC and $1 \times$ MIC in this study is achieved in a shorted period of time $(2 \mathrm{~h})$.

It is well known that the antimicrobial activity of AgNPs is mainly attributed to the interaction between the negative charge on the cell membrane of microorganisms and functional groups on its surface and the positive charge of the nanoparticles. However, dynamic light scattering experiments, which measure Brownian motion and relates it to particle size, could suggest that the antimicrobial activity found in this study by AgNPs biosynthesized by S. queretaroensis peel is also related to the interruption of respiration and cell division cycles causing a lysis due to the AgNPs size since they have a larger area of contact with microorganisms [33].

Due to its antimicrobial effects at low concentrations, it is recommended to test more pathogens for microbicidal activity. Moreover, stability and toxicity tests should be conducted on these nanoparticles in order to obtain a safe and s product that can be used to clean living and inert surfaces and synthesize nanoparticles of $S$. queretaroensis peel from other metals besides silver.

\section{Conclusions}

Silver nanoparticles were successfully biosynthesized using the aqueous extract of the fruit peel of $S$. queretaroensis as a reducer. These nanoparticles tested at a low concentration displayed potent antimicrobial activity against gram-negative bacteria (E. coli, S. enterica and P. aeruginosa), gram-positive bacteria (S. aureus and MRSA) that cause foodborne illness, and the opportunistic medical pathogenic fungus $C$. albicans, which causes candidiasis. Therefore, these S. queretaroensis-mediated silver nanoparticles could be the basis for the formulation of biofilms for packaging products or as disinfectants for use on different surfaces.

Author Contributions: Conceptualization, E.P.-C., J.M.F.-F. and E.D.; experiment design, E.P.-C., J.M.F.-F. and I.M.S.-H.; formal analysis, I.M.S.-H., O.R.T.-G. and P.R.-R.; writing-original draft preparation, I.M.S.-H. and O.R.T.-G.; writing-review and editing, E.P.-C., J.M.F.-F. and H.W.; visualization, E.D. and H.W.; Supervision, E.P.-C., J.M.F.-F. All authors have read and agreed to the published version of the manuscript.

Funding: This research received no external funding.

Institutional Review Board Statement: Not applicable.

Informed Consent Statement: Not applicable.

Data Availability Statement: The data underlying this article will be shared on reasonable request from the corresponding author.

Acknowledgments: We thank Maria Fernanda Paez Gomez for the schematic representation of the biosynthesis process and the aqueous extract.

Conflicts of Interest: The authors declare no conflict of interest.

\section{References}

1. Halima, R.; Archna. A Review on Green Synthesis of Silver Nanoparticle, Characterization and Optimization Parameters. Int. J. Res. Eng. Technol. 2016, 5, 49-53. [CrossRef]

2. $\quad$ Akter, M.; Sikder, M.T.; Rahman, M.M.; Ullah, A.K.M.A.; Hossain, K.F.B.; Banik, S.; Hosokawa, T.; Saito, T.; Kurasaki, M. A Systematic Review on Silver Nanoparticles-Induced Cytotoxicity: Physicochemical Properties and Perspectives. J. Adv. Res. 2018, 9, 1-16. [CrossRef] 
3. Firdhouse, M.J.; Lalitha, P. Biosynthesis of Silver Nanoparticles Using the Extract of Alternanthera Sessilis-Antiproliferative Effect against Prostate Cancer Cells. Cancer Nanotechnol. 2013, 4, 137-143. [CrossRef] [PubMed]

4. Montoya, L.H.P.; Villarroel, I.M.Z.; Rojas, N.P.; Cabrera, N.P.; Calvimonte, O.R. Infecciones Intrahospitalarias: Agentes, Manejo Actual Y Prevención. Rev. Cient. Cienc. Med. 2010, 13, 90-94.

5. Patel, N.; Kasumbwe, K.; Mohanlall, V. Antibacterial Screening of Gunnera Perpensa-Mediated Silver Nanoparticles. J. Nanotechnol. 2020, 2020, 1-7. [CrossRef]

6. Mikhailov, O.V.; Mikhailova, E.O. Elemental Silver Nanoparticles: Biosynthesis and Bio Applications. Materials 2019, $12,3177$. [CrossRef]

7. Shah, A.T.; Din, M.I.; Bashir, S.; Qadir, M.A.; Rashid, F. Green Synthesis and Characterization of Silver Nanoparticles Using Ferocactus Echidne Extract as a Reducing Agent. Anal. Lett. 2015, 48, 1180-1189. [CrossRef]

8. Pooja, S.; Vidyasagar, G.M. Biosynthesis of Silver Nanoparticles from Three Opuntia Sps. Int. J. Adv. Sci. Res. Manag. 2019, 4, 1-11.

9. Quiroz-gonzález, B.; García-mateos, R.; Corrales-garcía, J.J.E.; Colinas-León, M.T. Pitaya (Stenocereus Spp.): An under-Utilized Fruit. J. Prof. Assoc. Cactus Dev. 2018, 20, 82-100.

10. Castro-Enríquez, D.D.; Montaño-Leyva, B.; Del Toro-Sánchez, C.L.; Juárez-Onofre, J.E.; Carvajal-Millán, E.; López-Ahumada, G.A.; Barreras-Urbina, C.G.; Tapia-Hernández, J.A.; Rodríguez-Félix, F. Molecules E Ff Ect of Ultrafiltration of Pitaya Extract. Molecules 2020, 25, 281. [CrossRef]

11. Arriaga-Ruiz, M.C.; Neri-Luna, C.; Pimienta-Barrios, E.; Sanchez-Martinez, J. El Fruto Del Pitayo Silvestre (Stenocereus Queretaroensis (Weber) Buxbaum), Una Alternativa Alimenticia, Nutricional, Y Socioeconómica En Época de Estiaje. Rev. Cienc. Nat. Agropecu. 2015, 2, 362-367.

12. Rivas-Morales, C.; Oranday-Cárdenas, M.A.; Verde-Star, M.J. Investigación En Plantas de Importancia Médica; OmniaScience: Barcelona, Spain, 2016. [CrossRef]

13. Loo, Y.Y.; Chieng, B.W.; Nishibuchi, M.; Radu, S. Synthesis of Silver Nanoparticles by Using Tea Leaf Extract from Camellia Sinensis. Int. J. Nanomed. 2012, 7, 4263-4267. [CrossRef]

14. Marinova, D.; Ribarova, F.; Atanassova, M. Total Phenolics and Total Flavonoids in Bulgarian Fruits and Vegetables. J. Univ. Chem. Technol. Metall. 2005, 40, 255-260.

15. Ezeonu, C.S.; Ejikeme, C.M. Qualitative and Quantitative Determination of Phytochemical Contents of Indigenous Nigerian Softwoods. New J. Sci. 2016, 2016, 1-9. [CrossRef]

16. Ejikeme, C.M.; Ezeonu, C.S.; Eboatu, A.N. Determination of Physical and Phytochemical Constituents of Some Tropical Timbers Indigenous To Niger Delta Area of Nigeria. Eur. Sci. J. 2014, 10, 247-270.

17. Bagul, S.U.; Sivakumar, S.M. Antibiotic Susceptibility Testing: A Review on Current Practices. Int. J. Pharm. 2016, 6, 11-17.

18. Clinical and Laboratory Standards Institute (CLSI). Performance Standards for Antimicrobial Susceptibility Testing, 30th ed.; CLSI Supply M100; Clinical and Laboratory Standards Institute: Wayne, PA, USA, 2020.

19. Grabowska, K.; Wróbel, D.; Żmudzki, P.; Podolak, I. Anti-Inflammatory Activity of Saponins from Roots of Impatiens Parviflora DC. Nat. Prod. Res. 2020, 34, 1581-1585. [CrossRef]

20. Olivas-Aguirre, F.J.; Wall-Medrano, A.; González-Aguilar, G.A.; López-Díaz, J.A.; Álvarez-Parrilla, E.; De La Rosa, L.A.; Ramos-Jimenez, A. Taninos Hidrolizables; Bioquímica, Aspectos Nutricionales Y Analíticos Y Efectos En La Salud. Nutr. Hosp. 2015, 31, 55-66. [CrossRef]

21. Padilla-Camberos, E.; Flores-Fernández, J.M.; Canales-Aguirre, A.A.; Barragán-Álvarez, C.P.; Gutiérrez-Mercado, Y.; LugoCervantes, E. Wound Healing and Antioxidant Capacity of Musa Paradisiaca Linn. Peel Extracts. J. Pharm. Pharmacogn. Res. 2016, 4, 165-173.

22. Goszcz, K.; Duthie, G.G.; Stewart, D.; Leslie, S.J.; Megson, I.L. Bioactive Polyphenols and Cardiovascular Disease: Chemical Antagonists, Pharmacological Agents or Xenobiotics That Drive an Adaptive Response? Br. J. Pharmacol. 2017, 174, 1209-1225. [CrossRef]

23. Roy, A. A Review on the Alkaloids an Important Therapeutic Compoundfrom Plants. Int. J. Plant. Biotechnol. $2017,3,9$.

24. Loo, Y.Y.; Rukayadi, Y.; Nor-Khaizura, M.A.R.; Kuan, C.H.; Chieng, B.W.; Nishibuchi, M.; Radu, S. In Vitro Antimicrobial Activity of Green Synthesized Silver Nanoparticles against Selected Gram-Negative Foodborne Pathogens. Front. Microbiol. 2018, 9, 1-7. [CrossRef] [PubMed]

25. Arokiyaraj, S.; Arasu, M.V.; Vincent, S.; Prakash, N.U.; Choi, S.H.; Oh, Y.K.; Choi, K.C.; Kim, K.H. Rapid Green Synthesis of Silver Nanoparticles from Chrysanthemum Indicum Land Its Antibacterial and Cytotoxic Effects: An in Vitro Study. Int. J. Nanomed. 2014, 9, 379-388. [CrossRef]

26. Hemmati, S.; Rashtiani, A.; Zangeneh, M.M.; Mohammadi, P.; Zangeneh, A.; Veisi, H. Green Synthesis and Characterization of Silver Nanoparticles Using Fritillaria Flower Extract and Their Antibacterial Activity against Some Human Pathogens. Polyhedron 2019, 158, 8-14. [CrossRef]

27. Kharat, S.N.; Mendhulkar, V.D. Synthesis, Characterization and Studies on Antioxidant Activity of Silver Nanoparticles Using Elephantopus Scaber Leaf Extract. Mater. Sci. Eng. C 2016, 62, 719-724. [CrossRef] [PubMed]

28. Aguirre, D.P.R.; Loyola, E.F.; De la Fuente Salcido, N.M.; Sifuentes, L.R.; Moreno, A.R.; Marszalek, J.E. Comparative Antibacterial Potential of Silver Nanoparticles Prepared via Chemical and Biological Synthesis. Arab. J. Chem. 2020, 13, 8662-8670. [CrossRef]

29. Ahmed, M.J.; Murtaza, G.; Mehmood, A.; Bhatti, T.M. Green Synthesis of Silver Nanoparticles Using Leaves Extract of Skimmia Laureola: Characterization and Antibacterial Activity. Mater. Lett. 2015, 153, 10-13. [CrossRef] 
30. Lima, A.K.O.; Vasconcelos, A.A.; Júnior, J.J.V.S.; Escher, S.K.S.; Nakazato, G.; Júnior, P.S.T. Green Synthesis of Silver Nanoparticles Using Amazon Fruits. Int. J. Nanosci. Nanotechnol. 2019, 15, 179-188.

31. Qais, F.A.; Shafiq, A.; Khan, H.M.; Husain, F.M.; Khan, R.A.; Alenazi, B.; Alsalme, A.; Ahmad, I. Antibacterial Effect of Silver Nanoparticles Synthesized Using Murraya Koenigii (L.) against Multidrug-Resistant Pathogens. Bioinorg. Chem. Appl. 2019, 2019, 1-11. [CrossRef]

32. Rautela, A.; Rani, J.; Debnath, M. Green Synthesis of Silver Nanoparticles from Tectona Grandis Seeds Extract: Characterization and Mechanism of Antimicrobial Action on Different Microorganisms. J. Anal. Sci. Technol. 2019, 10, 1-10. [CrossRef]

33. Mittal, A.K.; Kaler, A.; Banerjee, U.C. Free Radical Scavenging and Antioxidant Activity of Silver Nanoparticles Synthesized from Flower Extract of Rhododendron Dauricum. Nano Biomed. Eng. 2012, 4, 118-124. [CrossRef] 